\title{
Record
}

\section{Two French Hydrographers}

The recent deaths of Professor Hugon and Commandant Oudet (to give them the titles by which they were best known in this country), both Gold Medallists and Honorary Members of this Institute, take one back to a period, some twenty to thirty years ago, when the Institutes, and more particularly those of Britain, France and Germany, were engaged in a work of fundamental importance to navigation at sea which culminated in the formation of the International Association of Institutes of Navigation with consultative status to IMO, and later ICAO. These two distinguished members of the French naval hydrographic service played a prominent part in all these activities.

Pierre Hugon, Professor-en-chef de première classe d'hydrographie, with important responsibilities for French nautical education, resigned from his post in 1955, and in 1960 became full-time Secretary General of the French Institute of Navigation which had been formed in 1953 with Captain R. Ch. Duval in charge of the administration and Hugon as Secrétaire de Rédaction and editor of the review Navigation, around which the membership was built up. He was widely regarded as the founding father of the Institute, and was most certainly its mainstay. The precise circumstances of the foundation caused him some wry amusement in later years when he would occasionally refer to me as 'notre fondateur', for it was Hugon's dogged refusal to countenance the possibility of a French branch of the British Institute that finally persuaded the authorities to form a French body of the same kind. The possibility had been very informally discussed when I went to Paris in $195^{1-2}$ to visit Capitaine de Vaisseau Bergeret, under whom I had served at sea at one stage during the war, and who was later seconded to the hydrographic service. At this stage, our own Institute was already well established with an influential journal and it seemed a possible way of channelling interest to form a French branch. The idea was sympathetically enough received and the Service Central Hydrographique joined the Institute as a corporate member. However, in the event, the more ambitious path was chosen, and from then on Hugon was to devote his considerable energy and talents to what in effect became his life's work.

Hugon had an astonishingly wide range of navigational interests and knowledge. He was author of textbooks on marine radar, radio aids, and astronomical navigation and published sight reduction tables; he compiled the Consol tables in the French sailing directions and proposed a method of sight reduction that one high authority at least (Sadler) held to be, in principle, the most satisfactory ever devised. The flow of papers under his name seemed endless, the subjects astonishingly varied. His writing was characterized by close attention to detail and that (very French) approach to matters which we would term Cartesian. But he had a profound sense of style and it did not surprise me to learn that his earliest ambitions had been literary rather than scientific. I came to appreciate his elegant use of language whilst translating some of his papers for the Journal, and through his own sensitive translation of some of my accounts of Jester's voyages which were published in Navigation.

He was not easy to work with, and our long association over some thirty years at times resembled a form of guerrilla warfare. Most of the disagreements (they were not misunderstandings) arose from our different conceptions of the role of the Institutes and 
so how they could best work together. The work in question was generally that of the successive international working groups (whose membership was not confined to the Institutes) formed to carry on work ostensibly initiated by the series of tripartite meetings between the British, French and German Institutes of Navigation to study a wide range of (mostly) maritime problems from radar and the collision regulations to traffic separation at sea. Hugon's view, which was not widely shared, was that each Institute should form its own conclusions about the matters at issue; mine (and I was coordinating the work) that things would work better if members of the working group spoke as individuals rather than delegates. The difference may sound arcane but it went to the root of how we went about things. I got to understand Hugon's difficulties better when drawing up the by-laws for IAIN. As an illustration, it would I think have been awkward in Hugon's view for the French Institute to adopt a position in any public forum on a technical issue that was contrary to that of its government. This was not our position. One practical consequence of this difference of view was that Commandant Oudet, who had made important contributions to the study of traffic regulation at sea, was always nominated for membership of the appropriate working groups by the British Institute (of which he was a member) rather than the French (of which he was not). But if there were stormy passages in our long association, it was fundamentally one of respect and friendship; otherwise it would never have worked.

Though far from austere, with a dry sense of humour, Hugon was very much a private man. Sometimes he would talk of his childhood in Indochina, or of his seagoing days in the Pacific; but I would like to have known more of the inner man. It was only through the panegyric preached by a Dominican friar at his funeral, for example, that I learned of his deep interest in theology.

The chosen mission of Capitaine de Vaisseau (or Commandant as he preferred to be called after his retirement) Louis Oudet was to the seaman - the man on the bridge. For him, there were no abstract questions at sea, only human problems which he tried to see through the eyes of those who had to solve them. When I first got to know him he was in charge of sailing directions for part of the western approaches to the English Channel, and he conducted a lively correspondence with many of the shipmasters who used it. I think it was this that sparked off his interest in the collision problem generally, and in the Dover Strait in particular. Whenever possible he would take passage in crosschannel ferries to see for himself the problems of the master. He wrote a large number (some 24) of papers for the Journal, mostly of an expository kind, on a wide range of subjects from the wreck of the Antilles to the flashing characteristics of lights, and of course many on the problems of collision at sea. His papers were always thoughtful and he had the rare capacity, in what was, after all, a technical subject, of engaging the reader's sympathy. He wrote a little book on radar and collision which I had translated and published over here, and a marvellous article on the lessons of the Torrey Canyon disaster which he later expanded into a short book which was published by the Institute.

Oudet's great contribution to navigation, however, was in the realm of traffic separation at sea, where his mastery of the subject and his zeal combined with an essentially pragmatic cast of mind to give his views tremendous authority in the successive working groups that were set up (from 1960 onwards when, with Poll, he presented the first paper on the subject) to advance matters. He spoke almost no English, but could follow the drift of a discussion and was an attentive listener. His interventions were few but frequently decisive, and always persuasive. Once again, he saw the problems as human, not technical, and understood why a shipowner would say one thing, a pilot another and a shipmaster yet another. Errare humanum est was one of his favourite maxims. 
On retirement Oudet went to live in Burgundy, and he wrote some excellent papers from there, generally generated by some marine disaster; but I don't think retirement suited him. We would correspond and occasionally meet, generally in Paris or Dieppe; sometimes I would go and stay with him in Burgundy where, his large number of children having now fled the nest, he lived quietly. His work for safety at sea had been accomplished.

Oudet was a devout Catholic, his fashion of thinking profoundly influenced by scholastic philosophy. He was also a romantic with a marked affection for England and it gave him great satisfaction that the routeing plan finally adopted by the Dover Strait working group should have been proposed by Captain Lynes, Master of the British Rail cross-channel ferry Maid of Orleans.

M.W.R.

\section{Rear Admiral Thomas D. Davies USN (Ret.)}

Rear Admiral Thomas D. Davies USN (Ret.) died in January of this year at the age of 76. He was a decorated Navy pilot who held several aviation records and also an expert and an innovator in the field of navigation. Most recently he received international attention for his investigation of Admiral Robert E. Peary's claim to have reached the North Pole in 1909.

Admiral Davies was born in Cleveland, Ohio, on 3 November 1914. After two years at the Case Institute of Technology, he entered the US Naval Academy and graduated with a Bachelor of Science in 1937. He also held the degree of Master of Science from George Washington University and was a distinguished graduate of the National War College. In 1942 he was designated a naval aviator, and during World War II he served in the Atlantic Theatre with the anti-submarine patrol forces. He is credited with sinking the German submarine U-604, for which he was awarded the Distinguished Flying Cross. He was also assigned to instruct pilots of the Brazilian Air Force in operational flying, for which Brazil awarded him the Order of the Southern Cross.

After the war he was assigned as Project Officer for development of the Neptune $\left(\mathrm{P}_{2} \mathrm{~V}\right)$ aircraft. In this capacity, he organized and directed a long-range flight from Perth, Australia to Columbus, Ohio. In 1946 he was pilot and commander of the Truculent Turtle, which established a new world distance record ( 1 I , 236 miles) - an aviation mark which stood for over 16 years. For this achievement he was awarded a second Distinguished Flying Cross by President Truman and the 'Comte de la Vaulx' medal by the Federation Aeronautique Internationale. After this epic flight he joined the staff of Rear Admiral Richard Byrd for the Antarctic operation 'Highjump. ' For this project he designed and tested the first skis for tricycle-gear aircraft. He also equipped two aircraft with special navigation and photographic equipment for use in mapping the Antarctic continent and invented and built a special 'Sky Compass' for flight operations near the magnetic poles, where conventional instruments were unreliable. This new compass was later incorporated into celestial navigation equipment used by commercial airlines for the early trans-polar flights to Europe. For his invention, he was awarded the Thurlow Award for the outstanding contribution to the science of navigation for 1949.

Admiral Davies' later naval duties included tours in Europe and in the Orient. During the Cuban Missile Crisis he commanded Fleet Airwing 3 based in Brunswick, Maine, which was an important part of US aerial surveillance forces. As a Flag Officer he served as a special assistant to the Secretary of the Navy, was Commander of Carrier Division 